\section{DANAS PROOF OF DARWIN'S THEORY OF CORAL REEFS.}

I AMES DWIGHT DANA, born four years to a day after Darwin, on February 12, $18 \mathrm{I}_{3}$, naturalist of the United States Exploring Expedition under Wilkes from 1838 to 1842 , and afterwards until his death in 1895 professor of geology at Yale University, was for more than half a century a leading figure among American men of science. On the hundredth anniversary of his birth it is fitting to direct attention to the independent proof that he found many years ago for Darwin's theory of coral reefs, a proof that has long been overlooked, although it supplies the most important confirmation for the theory of subsidence that has ever been brought forward.

Darwin most ingeniously invented his theory of subsidence while he was in South America, before he had seen a true coral reef; he had afterwards only to test the theory by comparing its consequences with the facts that he observed during the voyage of the Beagle across the Pacific and Indian Oceans, and with the records of other explorers which he studied after his return home. The theory bore the test admirably ; it was universally regarded as "true" for a generation, although apart from certain correlations of coral reefs with areas of recent uplift and with active and extinct volcanoes, which appear to be less assured now than seventy years ago, the theory of subsidence did not gain that increased probability of correctness which comes to a theory from the capacity to explain facts that were unknown or unnoticed when the theory was invented.

During the last thirty years several new theories of coral reefs have been introduced, and Darwin's theory has been more or less discredited in the minds of some investigators. Murray re-introduced what may be called the theory of outward growth, which Darwin had considered and adopted for certain special cases in association with subsidence; but in its new form subsidence was excluded from this theory, and two provisos were added as to the organic upbuilding of submarine banks until they reach the moderate depth at which they may serve as foundations for atolls, and as to the production of lagoons by the removal of the inner part of reefs by solution (Proc. Roy. Soc., Edin., ix:, 1880, 505-518). Agassiz, in his world-wide explorations of coral reefs, emphasised the possible complications in their history; he pointed out the frequent occurrence of uplifted "coralliferous limestones," which might be worn down and dissolved away while fringing reefs grew around them, thus producing barrier reefs and atolls in association with elevation instead of subsidence. At the same time he reintroduced the idea-which Darwin had rejected on good grounds--that reefs could grow on the outer margin of platforms cut by the waves around volcanic islands, thus producing barrier reefs without subsidence, elevation, or solution (Bull. Mus. Comp. Zool., xxxiii., 1899; Mem. Mus. Comp. Zool., xxviii., 1903). Wharton went still farther in suggesting that a volcanic island might be worn down to a depth of twenty or twenty-five fathoms by marine agencies, thereby producing a flat submarine bank on which an atoll could afterwards grow up; thus accounting for atolls as Agassiz had for barrier reefs, without subsidence, elevation, or solution.

The possibility of producing barrier reefs and atolls by the wearing down of uplifted "coralliferous limestones," as suggested by Agassiz, may be regarded as a modification of any theory that will explain barrier reefs and atolls before the uplifts occurred. Darwin recognised at least one instance of wearing down an uplifted reef ("Coral Reefs," r842, p. 55), and would certainly have welcomed the larger application of this process, had he known the results of modern exploration.

The formation of atolls by up-growth from submarine banks of proper depth is eminently possible, if the banks can be provided in sufficient number, but possibility is not proof. When subsidence is demonstrated as having taken part in the production of barrier reefs, as will be shown below, its exclusion from this theory of atolls is unreasonable.

The development of a foundation of atolls by the marine truncation of a volcanic island, as indicated by Wharton, is eminently possible, provided that fioating coral larvæ do not establish themselves upon it until truncation is complete; but the ordinary rela. tion of fringing and barrier reefs to their central islands shows that this proviso is inadmissible. The formation of a fringing reef will be begun as soon as a narrow platform is abraded, and such a reef once established, further truncation of the island by wave work is practically stopped. Moreover, the Alexa and other submarine banks described by Wharton can be explained by regarding them as submerged atolls quite as well as by regarding them as truncated volcanic islands; hence this theory is not satisfactory.

The formation of veneering barrier reefs on the outer margin of sea-cut platforms around still-standing islands, an old idea (see footnote in Darwin's "Coral Reefs," r842, p. 49) recently given prominence by Agassiz, is open to the same difficulty that is fatal to Wharton's theory of truncation. However, if a barrier reef were ever formed in this manner, the central island should rise from the cut-back shore line in a wall of steep cliffs, as Darwin clearly stated, and the broader the platform, the simpler the outline of the cliff-walled island should become. It may be confidently asserted that the central islands of barrier reefs do not possess these significant features; hence there is no more reason for accepting this theory to-day than when Darwin rejected it.

The theory of outward growth and solution, advocated by Murray for the production of barrier reefs around volcanic islands, without subsidence, or even in areas of slow elevation, involves several conse. quences which, when compared with the facts, contradict its verity; for during the slow outward growth of the reef around a still-standing island, the streams from the mountainous interior must form deltas in the shallow water at their mouths, and by the time the reef has grown far enough outwards to be called a barrier, the delta plains must become more or less confluent laterally, thus forming a low alluvial plain around the original island, as Darwin clearly saw ("Coral Reefs," 1842, pp. 128-130). When such lowlands occur, they indicate a still-stand of the island; but their prevailing absence suffices to exclude the general application of the postulated stillstand.

It would thus appear that the theories of outward growth and solution for the production of barrier reefs, of marine truncation for the production of atolls, and of coral veneers on the margin of sea-cut platforms for the origin of barrier reefs, all fail to satisfy the requirements of observation, when they are tested by certain consequences that have not been explicitly stated by their inventors. It remains to be seen whether Darwin's theory of subsidence suffers the same fate when tested in the same manner.

The accompanying diagram (Fig. I) exhibits three stages in the subsidence of a dissected volcanic island; the first stage shows a fringing reef, the second a barrier reef, the third an atoll, as indicated by Darwin's original figures, which are here reproduced in

NO. 2258 , VOL. 90] 
substance on the front face of each block. But the surface of the second block shows a feature which Darwin did not notice, although it is quite as essential a consequence of his theory as any other. This is the invasion of the previously eroded valleys of the subsiding island by the sea, so that the relatively simple shore line of the first stage is in the second stage transformed into an embayed shore line, possessing several of "those deep arms of the sea ... which," as Darwin said, "penetrate nearly to the heart of some encircled islands" ("Coral Reefs," r842, p. 49). So long as subsidence continues the bays cannot be filled with deltas and the ridges cannot be cut back in cliffs. Darwin recognised that the central island must diminish in size as it subsides, but he did not also perceive the necessary modification of its outline.

It requires but a brief examination of large-scale charts of the Pacific island-groups to discover that the central islands of barrier reefs are repeatedly characterised by an embayed shore line, that the bays
1839. Several months earlier, during "the ascent of Mt. Aorai on Tahiti, in September of 1839," he had conceived the production of an embayed shore line as a necessary result of the subsidence of a dissected land mass. Let it be noted in passing that he was the first clearly to announce this important principle, which then had no place in geology or geography, although it is hinted at in De la Beche's "Researches in Theoretical Geology" (London, I834, p. I93). In Dana's first report he says, when following Darwin in explaining barrier reefs and atolls by subsidence :"The very features of the land, the deep indentations, are sufficient evidence of subsidence to one who has studied the character of the Pacific islands" ("Freology," U.S. Expl. Exped., r849, p. 13I); and on a later page a more explicit statement is made under the general heading, "Evidence of Subsidence," and the special heading, "Deep Bay-indentations in Coasts as the Terminations of Valleys" :-_."In the remarks upon the valleys of the Pacific islands, it has been shown that they were in general formed by

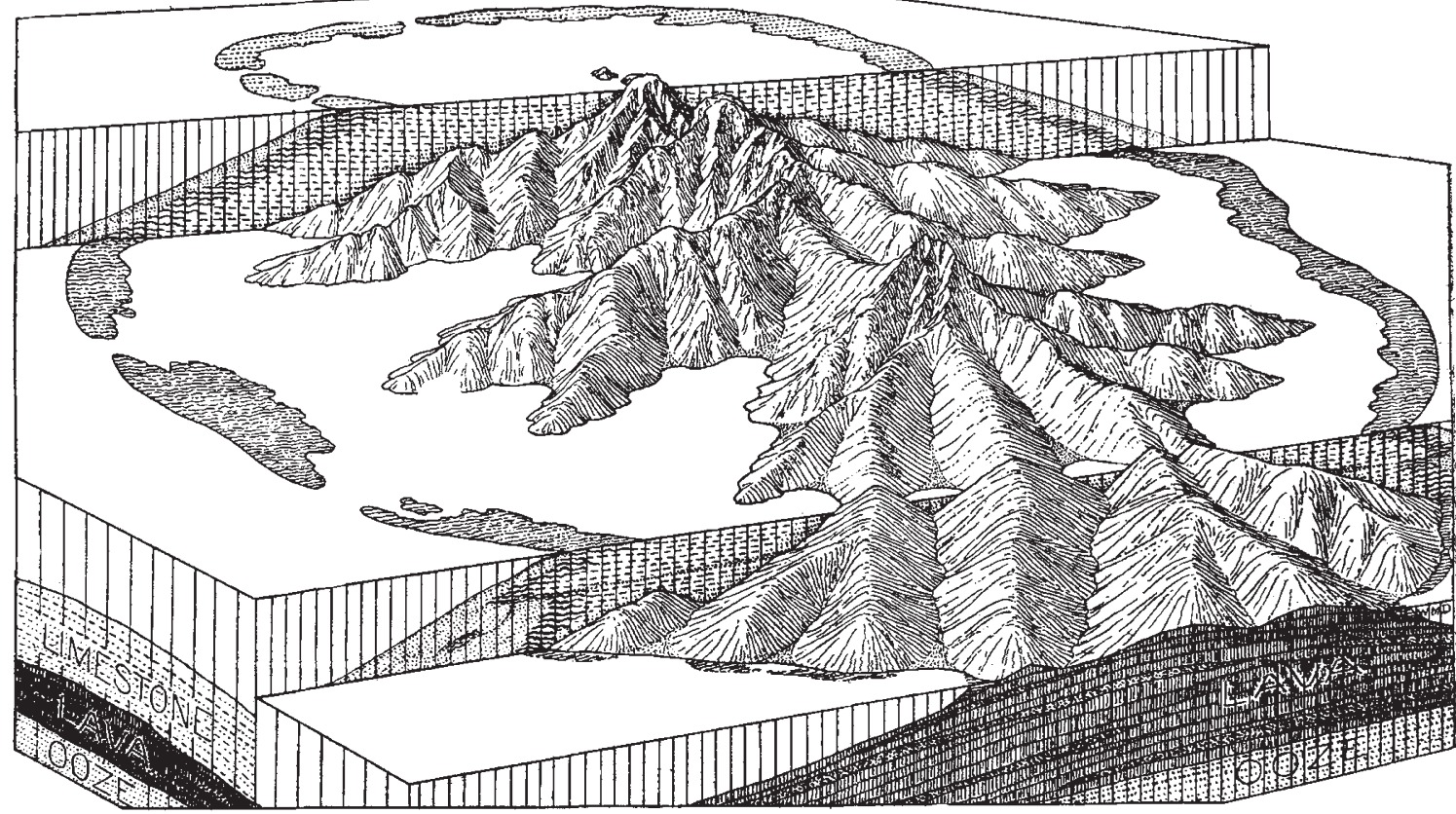

FIG. x.-Stages in the subsidence of a dissected volcanic island.

are not filled with delta-plains, and that the ridge ends are not truncated in cliffs. Kandavu and Mbengha in the Fiji group (Admiralty chart 167 ), the western members of the Society group (chart 1060), and especially Bora Bora (I428), Gambier Island (III2), a western member of the Paumotus, and Rossel Island (1473), in the Louisiade archipelago of British New Guinea, may be instanced among many others as affording good illustration of at least some of these features, particularly of embayed shore lines.

In view of the remarkable accordance that is thus found between the inferred consequences of the theory of subsidence and the observed features of central islands of barrier reefs, and in memory of the failure of corresponding consequences of other theories to match the facts, an open-minded inquirer cannot hesitate long in making choice among the several explanations that have been suggested for barrier reefs, and with them, of atolls.

Dana first learned of Darwin's theory when the Wilkes expedition reached Sydney near the end of NO. 2258 , VOL. 90] the waters of the land, unaided by the sea; that the sea tends only to level off the coast, or give it an even outline. When, therefore, we find the several valleys continued on beneath the sea, and their enclosing ridges standing out in long narrow points, there is reason to suspect that the island has subsided after the formation of the valleys. For such an island as Tahiti could not subside even a few scores of feet without changing the even outline into one of deep covies or bays, the ridges projecting out to sea on every side. . . The absence of such coves, on the contrary, is evidence that any subsidence which has taken place has been comparatively small in amount" (p. 393). Similar statements are made in Dana's first book on this subject, "On Coral Reefs and Islands" (New York, 1853, pp. II8-119), and in all the editions of his larger book, "Corals and Coral Islands" (New York, first edition, 1872, pp. 319-320; third edition, 1890, pp. 273-274).

It is remarkable how rarely the value of this capital point has been recognised. It is referred to in 
Bonney's appendix to the third edition of Darwin's "Coral Reefs" (London, I889, pp. 3I0-3II), but without sufficient indication of its value as an independent and therefore important confirmation of Darwin's theory. It is noted by Krämer, who gives it local application in explaining certain bays on the Samoan islands, but without recognising its value in relation to the theory of subsidence in general ("Bau der Korallenriffe," Leipzig, 1897, p. 24). It is quoted by Gardiner, but without understanding of its importance, for he adds: "Such evidence when applied to volcanic islands is, I submit, of very doubtful value" (Proc. Camb. Phil. Soc., ix., I898, p. 490). Murray does not refer to it; Agassiz quotes and rejects it in reference to the Marquesas Islands (Mem. Mus. Comp. Zool., xxviii., 1903, p. 5), and does not mention it elsewhere. Singularly enough, Darwin himself refers in the second edition of his book only twice, and then very briefly, to Dana's evidence of subsidence; both references concern the Marquesas Islands ("Coral Reefs," second edition, London, 1874, pp. I63, 201). I have found no other passage in which Darwin says a word upon the subject, although his discussion is otherwise marvellously complete. Dana's inference regarding the Marquesas is to be found in his report on the geology of the Wilkes Expedition (1849, p. 397), in his "Coral Reefs and Islands" (1853, p. 122), and in his "Corals and Coral Islands" (1872, p. $325 ; 1890, p$ 36r).

Doubtless other earlier writers cited Dana's principle, but it has not yet come to be generally accepted as an essential element in the demonstration that barrier reefs have been formed by subsidence. This is probabiv because an understanding of the reasonable evolution of coastal forms has not yet taken general possession of the scientific mind, or perhaps because some students of the coral-reef problem still adhere to the obsolete explanation of bays by marine erosion, an explanation that Dana explicitly excluded; can it possibly also be because there is as yet no sufficient understanding of the logical principle that a theory, even if it be well recommended by explaining the things that it was invented to explain, still neeas confirmation by independent, unexpected evidence, before it deserves to be accepted as "demonstrated"?

Several recent writers on the coral-reef problem, particularly those in Australia, have recognised the value of the evidence for subsidence given by drowned valleys. The latest of these is Marshall, of Otago, New Zealand. He writes as follows regarding the Societv Islands, in his recent essay on "Oceania" in the Handbücher der regionalen Geologie:- "The deep inlets that intersect the coast line ... are clearly due to stream erosion. Prolonged marine action would have shallowed or filled them, or at least would have built up bars of coastal débris across the entrances. The author is therefore strongly of opinion that the absence of cliffs at the termination of the radiating spurs, the presence of deep water in the lagoon, and of far-reaching inlets, prove that marine erosion has not had any influence on the form of these islands at the present sea-level. . . Finally, the deep inlets appear to be drowned stream valleys, and their nature strongly supports the belief that the islands have been subjected to an important movement of subsidence."

It is a pleasure to find a colleague who has a personal knowledge of coral islands and with whose opinion I can so closely unite, even though we are physically separated by the greatest distance that the earth affords. I am glad to join with him in emohasising the importance of Dana's principle as an independent confirmation of Darwin's theory of coral reefs.

NO. 2258 , VOL. 90] W. M. Davis.

\section{UNIVERSITY AND EDUCATIONAI INTELLIGENCE.}

CAMBridge.-The readership in forestry will be vacant on March $3 \mathrm{I}$ by the resignation of $\mathrm{Mr}$. A. Henry. The general board will in the Easter term appoint a reader. The annual stipend is $400 l$. Candidates are reauested to send their applications, with such testimonials as they think fit, to the ViceChancellor on or before April 15.

OXFORD.-On February 4 the decree providing for the allocation of a site on the south side of the University Park for the erection of an engineering laboratory was not moved.

The subject of Prof. D'Arcy Thompson's Herbert Spencer lecture on February I4 has been altered to "Aristotle as a Biologist."

Mr. R. H. Moody has been appointed professor of mathematics at the Muir Central College, Allahabad.

Mr. F. E. Armstrong has been appointed to the professorship of mining in the University of Sheffield in succession to Prof. Hardwick

A COURSE of three public lectures on the electrical properties of flames will be delivered in the Physics Theatre of University College, University of London, by Dr. E. N. da C. Andrade, on Mondays, February Io, 17 , and 24 , at 5 p.m.

THE first term of the newly formed University in Western Australia will open in March of this year. Three out of the eight chairs have been filled in England. That of chemistry will be taken by Dr. N. T. M. Wilsmore, and Dr. A. B. Ross will occupy the post of professor of mathematics and physics, both having left for Australia by R.M.S. Moldavia on January 30. Dr. Wilsmore has been associated with the University of London for some time, having held the position of assistant-professor of chemistry at University College. Dr. Ross has been assistantprofessor of natural philosophy in the University of Glasgow. Dr. W. J. Dakin, assistant professor in the department of zoology and comparative anatomy in University College, London, will proceed to Western Australia by R.M.S. Mongolia on February 7 , to occupy the chair of biology.

IN The Quarterly Journal of Forestry for January Prof. Fraser Story gives a short account of the School of Forestry at Selmeczbanya, Hungary. This school, which is about I5o miles north of Budapest, was founded in 1807 , and is thus one of the oldest forestry schools on the Continent. There is also a mining school in the same building, and the combined staff of the two includes twenty professors each with an average of two assistants. No fees are charged exrept a registration fee of less than $I l . ;$ on the other hand, liberal scholarships are provided by the Hungarian Government conditionally on the holders subsequently serving two years in the Government Forestry Department. As for the laboratory equipment, even the list of physical apparatus is on the most elaborate scale, the electrical instruments including galvanometers, amperimeters, voltameters, resistancs boxes, alternating-current generators, transformers, rheostats, accumulators, Röntgen-ray apparatus, and Ruhmkorff coils giving sparks more than 18 in. long.

THE New Zealand University Reform Association has for some three years been urging on the public the need of various reforms, both in the constitution of the Senate and of the governing bodies of the four affiliated colleges, as well as in the method of 